\section{Monitoring the Effects of Pulp and Paper Effluent Is Restricted in Genetically Distinct Populations of Common Bully (Gobiomorphus cotidianus)}

MICHAEL R. VAN DEN HEUVEL, ${ }^{*},+$ CHRISTIAN MICHEL, ${ }^{\ddagger}$ MARK I. STEVENS, $\$$ ANDREW C. CLARKE, $\$, \nabla$

KAI N. STÖLTING, \#

BRENDAN J. HICKS, $\perp$ AND

LOUIS A. TREMBLAY ${ }^{\times}$

Scion, Rotorua, New Zealand, Limnological Institute, University of Konstanz, Konstanz, Germany, Allan Wilson Centre for Molecular Ecology and Evolution, Massey

University, Palmerston North,

New Zealand, Institute of Molecular BioSciences, Massey

University, Palmerston North, New Zealand, Zoological

Museum, University of Zürich, Zürich, Switzerland,

Department of Biological Sciences, The University of Waikato, Hamilton, New Zealand, and Landcare Research,

Lincoln, New Zealand

The common bully (Gobiomorphus cotidianus), a smallbodied New Zealand native fish species, was used to monitor population impacts of multiple effluents in the Tarawera River, New Zealand. In an initial survey, the absence of reproductive development at the expected spawning time for common bully was observed in a population downstream of effluent discharges. Subsequently, we examined the hypotheses that the observed changes were due to effluent exposure, migratory patterns, or genetic differences between populations. Liver detoxification enzyme activity and stable isotopes provided evidence against upstream migration of sexually mature bully. The observed presence of developed gonads in the downstream population during winter season resulted in the rejection of the hypothesis that reproductive failure was due to effluent exposure, and it was concluded that there were substantial differences in reproductive timing. Genetic analyses of two upstream, one downstream, and one population from a nearby coastal river indicated the upstream (reference) and downstream (effluent exposed) bully in the river formed genetically distinct populations. The identification of a nearby river population with similar reproductive timing and high genetic similarity to the effluent-exposed population

* Corresponding author phone: 902-566-6072; fax: 902-566-0740; e-mail: mheuvel@upei.ca; current address: Canadian Rivers Institute, University of Prince Edward Island, Departments of Biology, 550 University Avenue, Charlottetown, Prince Edward Island, Canada C1A 4P3.

+ Scion.

¥ University of Konstanz.

$\$$ Allan Wilson Centre for Molecular Ecology and Evolution, Massey University

${ }^{\nabla}$ Institute of Molecular BioSciences, Massey University.

\# University of Zürich.

${ }^{\perp}$ The University of Waikato.

$\times$ Landcare Research. suggests that the observed differences in the genetics of the downstream population were not caused by effluent exposure. The genetic analysis did highlight the lack of downstream dispersion and gene flow in the river which could possibly be related to anthropogenic stress.

\section{Introduction}

The effective use of freshwater fishes as indicators of anthropogenic impact require that the target species must be resident at that site long enough to elicit biological responses. The ability to rapidly capture fish of all life stages from a population also facilitates assessment of population responses (1). Chosen species must be sufficiently abundant to allow the collection of statistically significant sample sizes without impacting the population. The availability of appropriate reference sites is critical, as variation in environmental conditions among reference sites can cause substantial variability in population responses (2).

The common bully (Gobiomorphus cotidianus) (3) is a small-bodied fish species endemic to New Zealand. Of the other seven Gobiomorphus species in New Zealand, three are obligate diadromous species, three are non-diadromous, but only G. cotidianus is known to be facultatively diadromous, often leading to the establishment of land-locked populations (3). Sampling of small-bodied fishes has verified their value as indicator species (4). Small-bodied fishes like G. cotidianus also allow studies of smaller and more diffuse discharges in low-order streams (5). An increase in the successful use of fish in assessments of pulp mill effects between the first two cycles of the Canadian Environmental Effects Monitoring Program has been partly attributed to the increased use of small-bodied fishes (6).

One aspect rarely considered when interpreting or designing population health studies is genetic difference between populations. The majority of studies examining genetic diversity and pollution examine the hypothesis that anthropogenic stress can influence the genetics of exposed populations. This rapidly emerging area has been called 'evolutionary toxicology'. A number of studies have concluded that genetic differences due to toxicant exposure have occurred, including a study of pulp and paper mill effluent (7). However, others have found no changes due to contaminant stress and emphasize the importance of performing genetic studies within a biogeographical context (8). In yet other cases, adaptation or selection due to pollution responses has been clearly observed, but such adaptations have been difficult to relate to changes in genetic diversity (9).

In this study, the common bully was used as a monitoring species for the impacts of pulp and paper mill effluent. An initial survey indicated that upstream and downstream populations had dramatically different levels of reproductive development. In the course of this study we sought to examine whether these effects were due to the effluent input into the Tarawera River causing reproductive failure, or due to migratory patterns of the common bully populations, or due to inherent genetic differences between populations.

\section{Materials and Methods}

Study Site and Experimental Design. Samples were collected in the Tarawera River in the Bay of Plenty, North Island, New Zealand (Figure 1). Downstream of the township of Kawerau, the Tarawera River receives inputs from two pulp and paper mills, municipal waste, and effluent from a geothermal power plant (Figure 1). The two pulp and paper mills, having the 


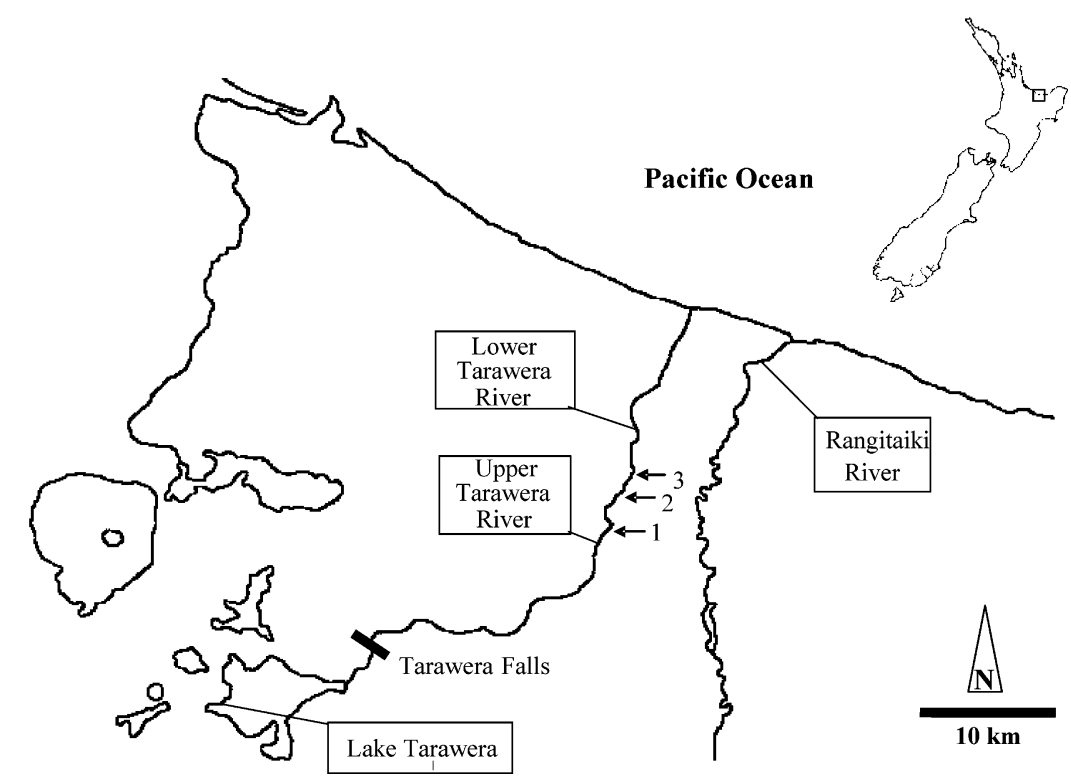

FIGURE 1. Sampling locations for common bully in the Tarawera and Rangitaiki River systems. Numbers indicate points of source inputs: (1) CTMP/municipal sewage effluent, (2) geothermal effluent, (3) bleached kraft/TMP effluent.

greatest discharge volumes, are of particular interest to the ecological health and management of the Tarawera River. In the lower reaches of the river, there are various agricultural land uses whereas in the upper reaches there are both native and pine plantation forests.

The first of the two pulp and paper mills produces approximately 110 tonnes/day of unbleached and peroxide bleached chemithermomechanical pulp (CTMP) and 160 tonnes/day of tissue paper. Mill furnish is composed of Pinus radiata and Eucalyptus spp. Mill effluent combined with Kawerau municipal sewage undergoes anaerobic treatment, and final treated CTMP effluent is discharged both directly to the river and to riverside rapid infiltration basins. The effluent dilution of this mill in the river is difficult to estimate because of the use of rapid infiltration basins, but based on maximum effluent volume entering the river, it would be approximately $1 \% \mathrm{v} / \mathrm{v}$. The second mill is an integrated thermomechanical (TMP)/bleached kraft (BK) pulp and paper mill, producing approximately 700 tonnes/day pulp and 950 tonnes/day newsprint paper. Furnish is predominately $P$. radiata with occasional pulping of Eucalyptus species. Pulp undergoes treatment with sodium hypochlorite $(\mathrm{HH})$ or chlorine dioxide (DEopDnD or DeopPD) and has been elemental chlorine free since 1998. TMP effluent was pretreated in an activated sludge bioreactor system before combination with the remaining effluent. Combined effluents are primary treated by passage through a coarse screen and gravity clarifier. Secondary treatment of effluent (discharge $175000 \mathrm{~m}^{3}$ /day) takes place in a 45 -ha aerated pond system with a retention time of $4-6$ days before final discharge to the Tarawera River. The mean dilution of the mill effluent in the river was $7.6 \% \mathrm{v} / \mathrm{v}$ in the year prior to the study. The Tarawera River is lake-fed, and due to the stable flow regime, seasonal changes in effluent dilution are negligible. The Tarawera River also receives geothermal fluid discharges from a bore field supplying steam to the pulp mill facilities. Exact data are not available for geothermal flows, though geothermal fluid discharge into the river was less than $1 \% \mathrm{v} / \mathrm{v}$.

An initial survey of the common bully was completed January $14-22,2003$, at two sites. The reference site just above the town of Kawerau is located approximately $1 \mathrm{~km}$ above the combined outfall of the upstream mill and municipal sewage and approximately $6 \mathrm{~km}$ above the outfall of the second mill. The effluent exposed site was approximately $3 \mathrm{~km}$ downstream of the outfall of the second mill. Geothermal effluent is released between the outfalls of the two mills. The reference and exposed sites are henceforth called Upper Tarawera River and Lower Tarawera River, respectively (Figure 1). Common bully were captured in minnow traps overnight. Additional sampling of the Tarawera populations was completed on July 17,2003 , and on January 30, 2004. Two additional populations from the nearby Rangitaiki River and Lake Tarawera were collected January 29, 2004, and September 1, 2004, respectively (Figure 1).

Fish Processing. Captured common bully were killed by an overdose of $0.1 \mathrm{~g} / \mathrm{L}$ tricaine methosulfonate (MS-222, SIGMA, St. Louis, MO), weighed $( \pm 0.01 \mathrm{~g})$, and measured (total fork length $\pm 1.0 \mathrm{~mm}$ ). For the 2004 sample period, blood was extracted from the caudal vein using a heparinized $0.5 \mathrm{~mL}$ syringe. A total of $50-150 \mu \mathrm{L}$ of blood was added to $50 \mu \mathrm{L}$ of $0.05 \mathrm{M}$ EDTA solution and immediately frozen at $-80{ }^{\circ} \mathrm{C}$. Dissected viscera, liver, spleen, and gonads were weighed $( \pm 0.001 \mathrm{~g})$. Carcasses were frozen at $-20{ }^{\circ} \mathrm{C}$ for isotope analysis. Otoliths were removed, cleaned, and stored dry until mounting in crystal bond. Grinding of otoliths was performed by hand using 4000 grit sandpaper followed by counting of annuli using a dissecting microscope.

7-Ethoxyresorufin-O-deethylase Activity. Hepatic 7ethoxyresorufin- $O$-deethylase (EROD) enzyme activity was estimated in post-mitochondrial supernatant as EROD (10). Liver extracts were homogenized in a cryo-preservative buffer (0.1 M phosphate, $1 \mathrm{mM}$ EDTA, $1 \mathrm{mM}$ dithiothreitol, and $20 \%$ glycerol, $\mathrm{pH} 7.4$ ) centrifuged at $9000 \mathrm{~g}$ to obtain the post mitochondrial supernatant (PMS). The EROD reaction mixture contained 0.1 M Hepes buffer, $\mathrm{pH} 7.8$ (SIGMA), 5.0 $\mathrm{mM} \mathrm{Mg}^{2+}, 0.5 \mathrm{mM}$ NADPH (Applichem, Darmstadt, Germany), $1.5 \mu \mathrm{M}$ 7-ethoxyresorufin (SIGMA), and about 0.5 $\mathrm{mg} / \mathrm{mL}$ PMS protein. The EROD activity was determined kinetically in 96-well plates using one reading every minute for 10 min on a BMG Polarstar Galaxy microplate fluorometer (BMG Labtechnologies, Offenburg, Germany). Resorufin was determined using 544-nm excitation and 590-nm emission filters. Protein content was estimated from fluorescamine fluorescence (390-nm excitation, 460-nm emission filters) against bovine serum albumin standards (SIGMA).

Stable Isotope Analysis. Ten or more adult female common bully of similar size range were selected from each site for stable isotope analysis. Skinless segments of white muscle of approximately $1 \mathrm{~g}$ were taken from the dorsal side 
TABLE 1. Mean (SEM, $n$ ) Condition Factor (K), Liver Somatic Index (LSI), Gonado-Somatic Index (GSI), and Hepatic 7-Ethoxyresorufin-0-deethylase Activity (EROD) for Common Bully Captured in the Tarawera and Rangitaiki Rivers in 2003 and $2004^{a}$

\begin{tabular}{|c|c|c|c|c|c|c|}
\hline \multirow[b]{2}{*}{$\begin{array}{l}\text { date/ } \\
\text { index }\end{array}$} & \multicolumn{3}{|c|}{ females } & \multicolumn{3}{|c|}{ males } \\
\hline & $\begin{array}{c}\text { Upper } \\
\text { Tarawera R. }\end{array}$ & $\begin{array}{c}\text { Lower } \\
\text { Tarawera R. }\end{array}$ & $\begin{array}{l}\text { Rangitaiki } \\
\text { River }\end{array}$ & $\begin{array}{c}\text { Upper } \\
\text { Tarawera R. }\end{array}$ & $\begin{array}{c}\text { Lower } \\
\text { Tarawera R. }\end{array}$ & $\begin{array}{l}\text { Rangitaiki } \\
\text { River }\end{array}$ \\
\hline $\begin{array}{l}\text { K } \\
\text { LSI } \\
\text { GSI } \\
\text { EROD }\end{array}$ & $\begin{array}{l}1.39(0.05,17)^{\mathrm{A}} \\
3.64(0.23,17)^{\mathrm{A}} \\
8.46(1.22,17)^{\mathrm{A}} \\
0.77(0.12,10)\end{array}$ & $\begin{array}{l}1.16(0.04,15)^{\mathrm{B}} \\
1.58(0.11,15)^{\mathrm{B}} \\
0.790(0.06,15)^{\mathrm{B}} \\
3.02(0.39,14)\end{array}$ & January 2003 & $\begin{array}{l}1.44(0.08,6)^{*} \\
2.51(0.42,6)^{\mathrm{A}} \\
0.67(0.15,6)^{\mathrm{A}} \\
1.3(0.2,6)\end{array}$ & $\begin{array}{l}1.28(0.03,14) \\
1.60(0.09,14)^{\mathrm{B}} \\
0.22(0.04,14)^{\mathrm{B}} \\
2.8(0.3,15)\end{array}$ & \\
\hline $\begin{array}{l}K \\
\text { LSI } \\
\text { GSI }\end{array}$ & & $\begin{array}{l}1.21(0.05,6) \\
2.03(0.24,6) \\
8.76(1.38,5)\end{array}$ & July 2004 & & $\begin{array}{l}1.34(0.05,9) \\
1.79(0.17,9) \\
0.83(0.08,9)\end{array}$ & \\
\hline & & & January 2004 & & & \\
\hline $\begin{array}{l}K \\
\text { LSI } \\
\text { GSI }\end{array}$ & $\begin{array}{l}1.25(0.028,13)^{\mathrm{A}} \\
2.73(0.15,13)^{\mathrm{A}} \\
7.26(1.13)^{\mathrm{A}}\end{array}$ & $\begin{array}{l}1.18(0.036,18)^{\mathrm{B}} \\
1.53(0.08,18)^{\mathrm{B}} \\
0.69(0.11,18)^{\mathrm{B}}\end{array}$ & $\begin{array}{l}1.34(0.029,16)^{\mathrm{A}} \\
1.50(0.11,16)^{\mathrm{B}} \\
0.66(0.0716)^{\mathrm{B}}\end{array}$ & $\begin{array}{l}1.34(0.05,10)^{*} \\
2.59(0.22,10)^{\mathrm{A}} \\
0.64(0.10,10)^{\mathrm{A}}\end{array}$ & $\begin{array}{l}1.17(0.03,17)^{\mathrm{A}} \\
1.49(0.14,17)^{\mathrm{B}} \\
0.24(0.03,17)^{\mathrm{B}}\end{array}$ & $\begin{array}{l}1.23(0.03,12)^{\mathrm{B}} \\
1.19(0.08,12)^{\mathrm{B}} \\
0.46(0.06,12)^{\mathrm{B}}\end{array}$ \\
\hline
\end{tabular}

a Means within each sex with different letters are significantly different at $p<0.05$. Asterisks ${ }^{*}$ ) indicate where a statistical interaction precluded analysis of site effects.

of the fish, dried for $48 \mathrm{~h}$ at $65^{\circ} \mathrm{C}$, ground into a fine powder with mortar and pestle, and stored in glass vials until analysis. Carbon and nitrogen stable isotopes were analyzed on a fully automated Europa Scientific 20/20 isotope analyzer $(11) . \delta^{13} \mathrm{C}$ results have a precision of $\pm 0.1 \%$ and were compared to a precalibrated $\mathrm{C}_{4}$ sucrose cross-referenced to Pee Dee belemnite. $\delta^{15} \mathrm{~N}$ results have a precision of $\pm 0.3 \%$ ond were compared to a urea standard that is traceable to atmospheric nitrogen.

Amplified Fragment Length Polymorphisms (AFLPs). AFLP fingerprinting was based on Vos et al. (12). Whole genomic DNA was extracted from $15 \mu \mathrm{L}$ of blood solution using a high salt extraction protocol (13). The DNA $(\sim 200$ ng) was digested using the restriction enzymes EcoR I (Invitrogen Inc., Karlsruhe, Germany) and Mse I (New England Biolabs). Complete digestion of the DNA was confirmed using electrophoresis on $1 \%$ agarose gels. For each sample, AFLP fingerprint profiles were generated with three selective primer combinations (one Mse I selective primer (Mse-CAA) combined with either one of three 5' fluorescently labelled $E c o$ R I selective primers (6FAM-Eco-ATAG, VIC-Eco-AATA, NEDEco-ATTA). The fluorescently labelled PCR products were combined with the GeneScan-500 LIZ (Applied Biosystems, Foster City, CA) size markers as an internal size standard. Samples were then subjected to capillary electrophoresis on a 3730 Genetic Analyzer (Applied Biosystems). Automated scoring was performed using GeneMapper3.7 (Applied Biosystems Inc., Foster City, CA) under default AFLP settings (50-500 bp peak range, $1 \mathrm{bp}$ bin width, $100 \mathrm{rfu}$ peak detection and labeling). Only loci with clear presence or absence of peaks in more than $95 \%$ of the samples were included in the analysis.

Statistical Analysis. Somatic indices were calculated as follows: condition factor $=($ fish mass - organ mass $) /($ total length $\left.{ }^{3}\right) \times 100$; liver somatic index (LSI) $=$ liver mass $/($ fish mass - organ mass $) \times 100$; gonadosomatic index $(\mathrm{GSI})=$ gonad mass / (fish mass - organ mass) $\times 100$. Statistical testing of differences between mean population site values of mass, liver size, and gonad size were carried out by analysis of covariance (ANCOVA). Differences in stable isotopes signature of the populations examined were analyzed by multivariate analysis of variance (MANOVA) using nitrogen and carbon isotope frequency as the dependent variables.

Length-at-age relationships were modeled using a modified von Bertalanffy equation of the following form: length $=L_{\max } \times\left(1-0.96 \mathrm{e}^{\left(-k \mathrm{Age}^{1.2)}\right)}\right)$ where $L_{\max }$ is the length at infinite time, or maximum length, and $k$ is the growth constant. Growth relationships were compared statistically using the residual sums of squares method of Chen et al. (14).

ARLEQUIN V3.01 (15) was used to calculate fixation indices based on pairwise distances between individuals $\left(F_{\mathrm{ST}}\right.$, 16) for AFLP profiles. For analyses, the significance level was set to $\alpha=0.05$ tested via 5040 permutations of individuals between defined groups. The $p$-values were Bonferroni corrected. To illustrate the individual genetic distances a neighbor-joining (17) dendrogram was created with MEGA3.1 (18) utilizing the Euclidean distance matrix created by ARLEQUIN V3.01 (15; Figure 5). Additionally an $F_{\mathrm{ST}}$ analogon $\left(\theta_{\mathrm{B}}\right)$ was calculated using the Hickory package (19). Genetic structure among sample locations was inferred with the software STRUCTURE 2.1 (20) under the admixture model without prior population information (500000 iterations, 100000 burn-in). We tested with a maximum number of $k=$ 6 clusters of individuals and repeated each run two times to ensure reproducibility. The critical level of significance for all statistical analyses was assessed at $\alpha=0.05$.

\section{Results}

Common bully captured in the Tarawera River in January 2003 had large mature ovaries and testes at the upstream site and small underdeveloped gonads at the effluent exposed site (Table 1). The gonads at the downstream site were translucent and homogeneous in color with no obvious signs that spawning had recently taken place. The physiological differences in reproductive status were also manifest in somatic indices such as greater condition factor and liver size at the downstream site (Table 1).

The possibility that sexually mature bully were migrating upstream was first examined to explain the dramatic differences in reproductive states in these populations. Liver monoxygenase enzymes as indicated by EROD activity were used in order to determine short-term residency. Both male and female common bully from Lower Tarawera exhibited an approximately 3-fold induction of EROD activity as compared to Upper Tarawera (Table 1). As liver enzymes can be activated and return to normal activity levels relatively rapidly, stable isotopes of carbon and nitrogen were utilized as a longer-term measure of residency. Common bully from Lower Tarawera showed approximately $5 \%$ o depletion in ${ }^{13} \mathrm{C}$ as compared to those from the Upper Tarawera site while the depletion in ${ }^{15} \mathrm{~N}$ was less than $1 \%$. Isotope signatures were significantly different $(p<0.001)$ between the Upper 


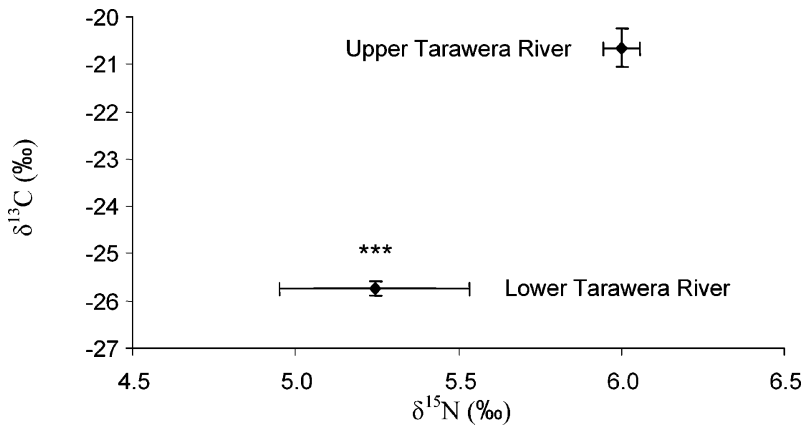

FIGURE 2. Mean stable isotope ratios for muscle tissue of common bully captured in the Tarawera River, January 2003. Error bars represent standard error of the mean. ${ }^{* * *} p<0.001$ as determined by MANOVA.

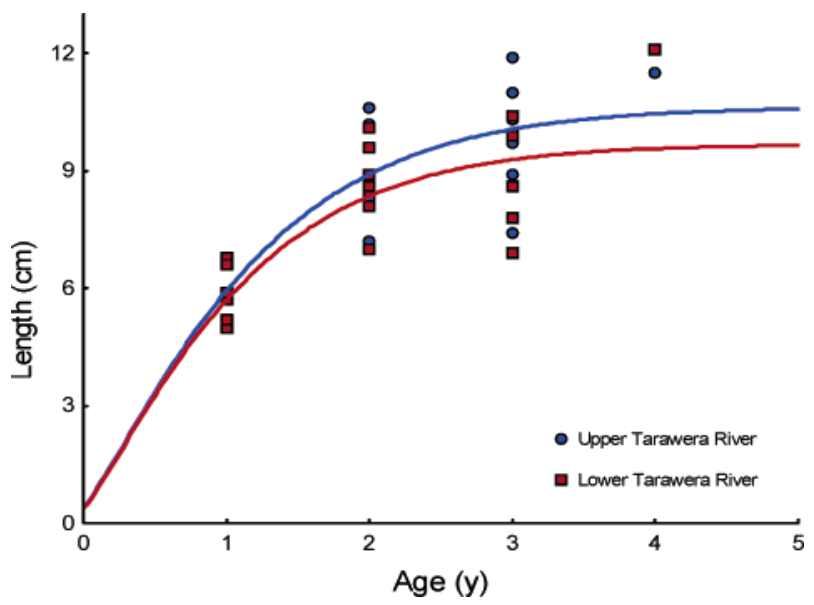

FIGURE 3. Length-age relationship in common bully captured in the Tarawera River, January 2003. Lines indicate the von Bertalanfy models fitted to the observed data. Blue line is the model for the Upper Tarawera River, and red line is the model for the Lower Tarawera River. The length-age relationship is not significantly different.

and Lower Tarawera bully populations, consistent with limited fish movement between the populations (Figure 2). The modeled age-size structure of the populations was not significantly different, further supporting the conclusion that mature bully do not move upstream to spawn (Figure 3).

Once established that significant movement between sites was not occurring, two remaining possibilities were explored: first, that effluent caused a failure in reproduction, and second, that the timing of reproduction at the downstream site varied from that at the upstream site. Common bully captured at the downstream site in late July 2003 had gonad sizes similar to those found upstream in January 2003 (Table 1), indicating that both populations of bully were developing reproductively, but timing of reproduction was significantly different. Subsequent studies have shown that the Upper Tarawera fish spawn in early February while the Lower Tarawera fish spawn in September/October (data not shown), representing at least a 4 month difference in spawning time. Common bully sampled from the nearby Rangitaiki River in January 2004 revealed a lack of reproductive development similar to that observed in the Lower Tarawera population in January 2003 and January 2004 (Table 1). Those fish captured from the Rangitiki were of similar age and size structure to the Lower Tarawera bully and thus were expected to be at the age of sexual maturity, and winter spawning was been verified subsequent to this study (data not shown).

In the AFLP analysis, a total of 708 loci were scored, with $92.8 \%$ polymorphism among all sample sites. A lower degree
TABLE 2. Pairwise $\boldsymbol{F}_{\mathrm{ST}}$ and $\boldsymbol{\theta}_{\mathrm{B}}$ Values among Sampled Populations $^{a}$

$\begin{array}{ccc}\text { Lake } & \text { Upper } & \text { Lower } \\ \text { Tarawera } & \text { Tarawera R. } & \text { Tarawera R. }\end{array}$

Upper Tarawera $\mathrm{R}$.

0.04

Lower Tarawera R. $0.19 * \quad 0.12^{*}$

$\begin{array}{lll} & 0.19 & 0.12 \\ \text { Rangitaiki R } & 0.12^{*} & 0.10^{*}\end{array}$

$0.10^{*} \quad 0.01$

$\begin{array}{lll}0.13 & 0.11 & 0.01\end{array}$

${ }^{a}$ Within each cell, $F_{\mathrm{ST}}$ values are the upper values and $\theta_{\mathrm{B}}$ values are the lower values. An asterisk $\left({ }^{*}\right)$ indicates significant differences at $p$ $<0.01$.

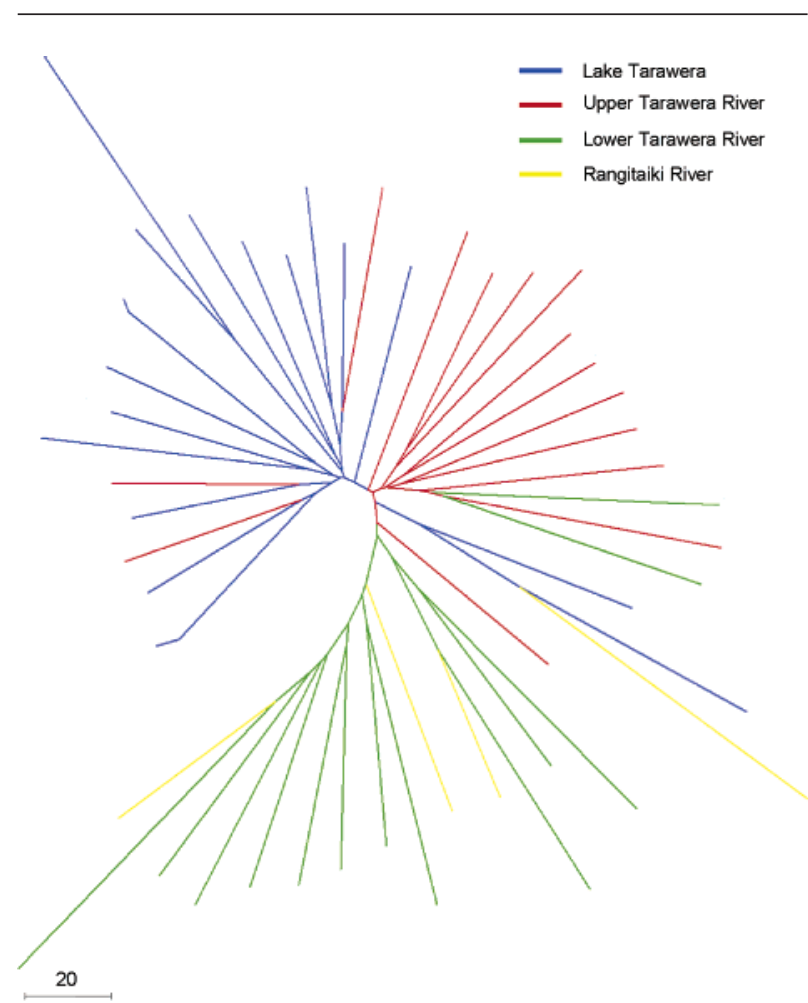

FIGURE 4. Neighbor-joining dendrogram illustrating the individual genetic distances. The scale bar represents a distance of 20 different peaks between AFLP profiles.

of polymorphism was found within populations (Lake Tarawera $=64.1 \%$, Upper Tarawera River $=54.0 \%$, Lower Tarawera River $=66.0 \%$, and Rangitaiki River $=43.8 \%$ ). Genetic data indicate significant differences between the downstream (Lower) and upstream (Upper) populations in the Tarawera River. The statistical test applied to the AFLP data $\left(F_{\mathrm{ST}}\right.$, Table 2$)$ revealed significant differences between the three populations within the Tarawera system (Table 2). The $F_{\mathrm{ST}}$ analogon $\theta_{\mathrm{B}}$, though not statistically testable, showed good agreement with $F_{\mathrm{ST}}$ values. Both the Upper Tarawera River and the Lake Tarawera populations showed significant genetic differences compared to the Lower Tarawera River population. Additionally, the two Tarawera River populations show the highest degree of genetic differentiation, yet they were the closest geographically. Differences between the Rangitaiki River and the Lower Tarawera River were not statistically significant, and $F_{\mathrm{ST}}$ and $\theta_{\mathrm{B}}$ indicated that those two populations were the most genetically similar of any test. In the dendrogram (Figure 4), three out of four specimens from the Rangitaiki River clearly cluster within the Lower Tarawera population.

The genetic structure indicated highest posterior probability for three distinct groups or genotypes within the sites 

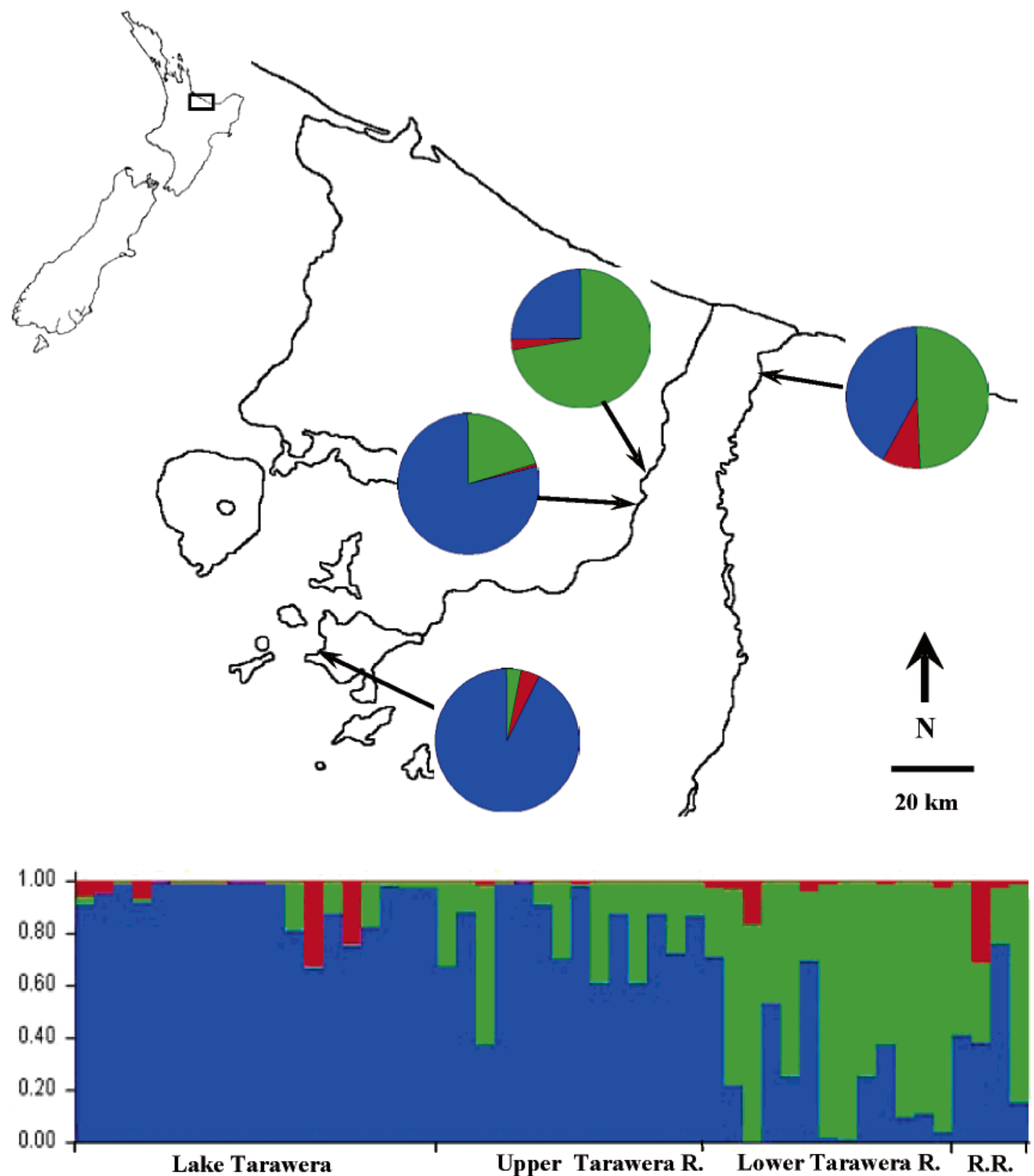

FIGURE 5. Genotypes in common bully captured in Lake Tarawera, Upper Tarawera River, Lower Tarawera River, and Rangitaiki River (R.R.), January 2004. Colors refer to genotypes. Bottom: Bar plot illustrating individual genotypic composition; each vertical bar represents one individual, $y$-axis $=$ proportion of genotypes. Top: Mean percentage of genotypes in individuals from each sample location.

examined $(\ln P(D)=-11.037, \mathrm{SD}=29.5$; Figure 5). One widespread (but uncommon) genotype present in all four sample sites (Type 1, red genotype, Figure 5) was found, with a mean percentage of $3.9 \%$. The two other genotypes show a more variable contribution to the four sample sites. The Type 2 (blue) genotype is present with the highest mean percentage in each individual in both the Lake Tarawera (92.5\%) and Upstream Tarawera River (79.0\%) population. In the Downstream Tarawera River population, the percentage of the Type 2 genotype drops to $25.4 \%$. Here the Type 3 (green) genotype has the highest mean proportion (72.2\%). In the other populations this genotype shows lower mean proportions of $3.5 \%$ in Lake Tarawera and $20.6 \%$ in the Upstream Tarawera River. The Rangitaiki River is similar to the Tarawera River in that it also shows a dominance of the green Type 3 genotype (49.2\%).

\section{Discussion}

Physiologically and reproductively distinct populations of the common bully were found upstream and downstream of the effluent outfalls, including that of pulp and paper mills. Despite the short distances between the populations and the absence of obvious physical barriers, a lack of reproductive development at the expected spawning time for common bully was observed in the Lower Tarawera population. A series of hypotheses were examined in order to determine if the observed changes were due to effluent exposure or other factors. The presence of developed gonads in the Lower Tarawera population in winter revealed that a failure of reproduction was not occurring. When genetic differences were examined, the Upper and Lower Tarawera populations showed differences that were much greater than those between the Upper Tarawera and the more distant 
Lake Tarawera. This finding was supported by liver enzyme activities consistent with previous studies on this river using other species of fish $(21,22)$. Stable isotopes also refute the upstream migration of sexually mature downstream fish during the spawning period, which is particularly interesting in light of comparable age and size structures of the populations.

Reproductive timing was clearly the most dramatic physiological difference associated with the effluent-exposed Lower Tarawera River population. However, the observation that the Rangitaiki River population spawns at a similar time period to the genetically indistinguishable Lower Tarawera River population shows that altered spawning time is, first, not unique to the Tarawera population and, second, can occur independently of the effluent outfalls. This comparison to the Rangitaiki at the physiological and genetic level suggests that altered spawning time in the Lower Tarawera River population is probably not pollution-induced. Unfortunately, relatively few Rangitiki samples were examined, and while those samples examined are clearly most similar to the Lower Tarawera, the low sample size leaves some uncertainty of how representative the sample is of the overall bully population in the Rangitiki River. These data are suggestive that the differences in reproductive timing are genetically mediated. The genetic data demonstrate that the Upper and Lower Tarawera populations are significantly distinct groups, and the EROD activity, isotope analysis, and differences in reproductive timing provide strong, independent lines of evidence that there is little significant movement through the effluent outfall zone. Even if there was some movement between the Upper and Lower populations, it is likely that the difference in reproductive timing would prevent interbreeding. Though reproductive timing may be a barrier to interbreeding, it would not be a barrier to downstream dispersal. The significant genetic differences separating the Upper and Lower Tarawera populations (despite their close proximity), the evidence against movement through this area, and probable mixing of the much more distant Lower Tarawera and Rangitaiki populations lead us to suggest the effluent outfalls represent a significant barrier to downstream dispersal.

Pulp and paper mills and other effluent sources on the Tarawera River have only been in operation for approximately 50 years. AFLPs are anonymous neutral genetic markers, which makes it highly unlikely that the $>700$ markers screened reflect one genetic region under selection in a period of $<50$ years. In previous years, prior to environmental improvements, effluents in the river may have been sufficiently toxic to deplete the downstream populations. The magnitude and duration of effluent exposure on the Tarawera River may have been sufficient to cause a genetic bottleneck with regards to particular loci. This study was designed to examine the physiological anomalies detected within the river, and the genetic techniques used are anonymous; therefore a more detailed genetic survey of coastal populations of the common bully is required to test the hypothesis of a genetic bottleneck/ founder effect. An alternative hypothesis is that the Lower Tarawera population is derived from a seagoing stock. Parallel research has examined nearly 20 populations of the common bully on both the North and South Island of New Zealand (authors' unpublished data), and thus far populations from Rangitaiki and Lower Tarawera River are the only populations that have been observed to spawn in early spring.

It seems most likely that the current distribution of different genotypes reflects the geological history of the region and the biogeographical history of the populations. The North Island of New Zealand is highly volcanic, and Lake Tarawera is central in the Okataina volcanic dome. This area has been subject to numerous cataclysmic geological events. The massive Taupo volcanic eruption of A.D. 186 probably eliminated freshwater fishes from most of the northeastern North Island (23) and is responsible for limited piscine diversity even into the present. Subsequent smaller eruptions of the Okataina dome, such as the Kaharoa eruption in ca. A.D. 1300 and the more recent Tarawera eruption of 1886, likely eliminated most fauna from Lake Tarawera. Trout and forage fish for trout were subsequently introduced into the Rotorua Lakes including Lake Tarawera in the late 1800s and early 1900s. These fish, including the common bully, were obtained from the Waikato River near the West coast of the North Island (24). Given the barrier of Tarawera Falls, it is not surprising that gene flow into the lake is limited, whereas there is ample opportunity for significant downstream (oneway) gene flow, probably assisted by a number of floods caused by the collapse of the lava flow that forms Lake Tarawera (25). Given the volcanic history, recolonization of the lower river reaches by diadromous common bullies may also have occurred. It is likely that multiple bottlenecks, extinctions. and recolonizations - caused by both natural (e.g., volcanic, flooding) and human-mediated (e.g., effluent disposal) events-have occurred.

We found no evidence that the altered reproductive timing in the Lower Tarawera is directly pollution-induced. However, we did find evidence that the presence of anthropogenic stress indirectly affected the population structures by establishing a barrier to gene flow. This could conceivably occur if summer spawning time is not favored downstream and any downstream migrants fail to reproduce successfully. In such a situation as was documented herein, comparing ecological and physiological patterns to assess anthropogenic impacts without a broader understanding of regional biogeographic patterns and biological processes may be misleading. Previous investigators have shown genetic differences in fish populations due to anthropogenic stress (9). Our study may partly support this, though not through an adaptive genetic mechanism. In the context of an environmental impacts study, the genetic differences may also have predated the anthropogenic stress. Many circumstances surrounding the bully populations in this study were specific to the species or to the sites examined, and the results are not intended to be broadly extrapolated to environmental impact studies as a whole. However, human introductions or recolonization from adjacent genetically distinct populations are not uncommon, and we would caution that unless the genetic background and biogeographical history of populations are considered when comparing ecotoxicological differences, such studies might be inherently flawed.

\section{Acknowledgments}

Funding is acknowledged from the New Zealand Ministry for the Environment Sustainable Management Fund, Norske Skog Tasman Mill, Environment Bay of Plenty, Carter Holt Harvey Consumer Brands, and the Foundation for Research, Science and Technology. The authors thank Dan Dietrich, Megan Finley, Joseph Butterworth, Ian Kusabs, and Tairua Whakaruru.

\section{Literature Cited}

(1) Gibbons, W. N.; Munkittrick, K. R. A sentinel monitoring framework for identifying fish population responses to industrial discharges. J. Aquat. Ecosyst. Health 1994, 3, 227-237.

(2) van den Heuvel, M. R.; Power, M.; MacKinnon, M. D.; Van Meer, T.; Dobson, E. P.; Dixon, D. G. Effects of oil sands related aquatic reclamation on yellow perch (Perca flavescens). I. Water quality characteristics and perch physiological and population responses. Can. J. Fish. Aquat. Sci. 1999, 56, 1213-1225.

(3) McDowall, R. M. New Zealand freshwater fishes: a natural history and guide; Heinemann Reed: Auckland, New Zealand, 1990; $553 \mathrm{p}$.

(4) Gibbons, W. N.; Munkittrick, K. R.; McMaster, M. E.; Taylor, W. D. Monitoring aquatic environments receiving industrial ef- 
fluents using small fish species 2: Comparison between responses of trout-perch (Percopsis omiscomaycus) and white sucker (Catostomus commersoni) downstream of a pulp mill. Environ. Toxicol. Chem. 1998, 17, 2238-2245.

(5) Gray, M. A.; Curry, R. A.; Munkittrick, K. R. Impacts of nonpoint inputs from potato farming on populations of slimy sculpin (Cottus cognatus). Environ. Toxicol. Chem. 2005, 24, 2291-2298.

(6) Lowell, R. B.; Ribey, S. C.; Ellis, I. K.; Porter, E. L.; Culp, J. M.; Grapentine, L. C.; McMaster, M. E.; Munkittrick, K. R.; Scroggins, R. P. National Assessment of the Pulp and Paper Environmental Effects Monitoring Data. National Water Research Institute Contribution. No. 03-521. Environment Canada \& National Water Research Institute, Canada, 2003.

(7) Theodorakis, C. W.; Lee, K.-L.; Adams, S. M.; Law, C. B. Evidence of altered gene flow, mutation rate, and genetic diversity in redbreast sunfish from a pulp-mill-contaminated river. Environ. Sci. Technol. 2006, 40, 377-386.

(8) Roark, S. A.; Nacci, D.; Corio, L.; Champlin, D.; Guttman, S. I. Population structure of a nonmigratory estuarine fish (Fundulus heteroclitus) across a strong gradient of polychlorinated biphenyl-contaminated and reference sites. Environ. Toxicol. Chem. 2005, 24, 717-725.

(9) Whitehead, A.; Anderson, S. L.; Kuivila, K. M.; Roach, J. L.; May, B. Genetic variation among interconnected populations of Catostomus occidentalis implications for distinguishing impacts of contaminants from biogeographical structuring. Mol. Ecol. 2003, 12, 2817-2833.

(10) van den Heuvel, M. R.; Munkittrick, K. R.; Stegeman, J. J.; Dixon, D. G. Second-round interlaboratory comparison of hepatic ethoxyresorufin-O-deethylase activity in white sucker (Catostomus commersoni) exposed to bleached kraft pulp mill effluent. Environ. Toxicol. Chem. 1995, 14, 1521-1527.

(11) Hicks, B. J.; Wipfli, M. S.; Lang, D. W.; Lang, M. E. Marinederived nitrogen and carbon in freshwater-riparian food webs of the Copper River Delta, southcentral Alaska. Oecologia 2005, 144, 558-569.

(12) Vos, P.; Hogers, R.; Bleeker, M.; Reijans, M.; van de Lee, T.; Hornes, M.; Frijters, A.; Pot, J.; Peleman, J.; Kuiper, M.; Zabeau, M. AFLP: a new technique for DNA fingerprinting. Nucleic Acids Res. 1995, 23, 4407-4414.

(13) Bruford, M. W.; Hanotte, O.; Brookfield, J. F. Y.; Burke, T. MultiLocus and Single-Locus DNA Fingerprinting. In Molecular
Genetic Analysis of Populations; Hoelzel, E. R., Ed.; Oxford University Press: New York, 1998; pp 283-336.

(14) Chen, Y.; Jackson, D. A.; Harvey, H. H. A comparison of von Bertalanffy and polynomial functions in modeling fish growth data. Can. J. Fish. Aquat. Sci. 1992, 49, 1228-1235.

(15) Excoffier, L. G. L.; Schneider, S. Arlequin ver. 3.0: An integrated software package for population genetics data analysis. Evol. Bioinf. Online 2005, 1, 47-50.

(16) Wright, S. Systems of mating. Genetics 1921, 6, 111 - 178.

(17) Saitou, N.; Nei, M.; The neighbour-joining method: a new method for reconstructing phylogenetic trees. Mol. Biol. Evol. 1987, 4, 406-425.

(18) Kumar, S.; Tamura, K.; Nei, M.; MEGA3: Integrated software for Molecular Evolutionary Genetics Analysis and sequence alignment. Briefings Bioinf. 2004, 5, 150-163.

(19) Holsinger, K. E.; Lewis, P. O. Hickory 1.0.3; 2001.

(20) Falush, D.; Stephens, M.; Pritchard, J. K. Inference of population structure using multilocus genotype data: linked loci and correlated allele frequencies. Genetics 2003, 164, 1567-1587.

(21) van den Heuvel, M. R.; Landman, M. J.; Tremblay, L. A. Responses of shortfin eel (Anguilla australis) to pulp and paper effluent using in situ exposures. J. Toxicol. Environ. Health 2006, 69, $1763-1779$.

(22) van den Heuvel, M. R.; Ellis, R. J. Timing of exposure to a pulp and paper effluent influences the manifestation of reproductive effects in rainbow trout. Environ. Toxicol. Chem. 2002, 21, 23382347.

(23) McDowall, R. M. Volcanism and freshwater fish biogeography in the northeastern North Island of New Zealand. J. Biogeogr. 1996, 23, 139-148.

(24) Burstall, P. J. The introduction of freshwater fish into Rotorua lakes. Rototua 1880-1980; Staford, D.; Steele, R.; Boyd, J., Eds.; Rotorua and district historical society: Rotorua, New Zealand 1980; pp 115-121.

(25) Hodgson, K. A.; Nairn, I. A. The c. AD 1315 syn-eruption and AD 1904 post-eruption breakout floods from Lake Tarawera Haroharo caldera, North Island, New Zealand. N. Z. J. Geol. Geophys. 2005, 48, 491-506.

Received for review August 10, 2006. Revised manuscript received December 13, 2006. Accepted January 12, 2007.

ES061922Q 